\title{
Retention of Riverine Sediment and Nutrient Loads by Coastal Plain Floodplains
}

\author{
Gregory B. Noe* and Cliff R. Hupp \\ U.S. Geological Survey, 430 National Center, Reston, Virginia 20192, USA
}

\begin{abstract}
Despite the frequent citation of wetlands as effective regulators of water quality, few quantitative estimates exist for their cumulative retention of the annual river loads of nutrients or sediments. Here we report measurements of sediment accretion and associated carbon, nitrogen, and phosphorus accumulation as sedimentation over feldspar marker horizons placed on floodplains of the non-tidal, freshwater Coastal Plain reaches of seven rivers in the Chesapeake Bay watershed, USA. We then scale these accumulation rates to the entire extent of non-tidal floodplain in the Coastal Plain of each river, defined as riparian area extending from the Fall Line to the upper limit of tidal influence, and compare them to annual river loads. Floodplains accumulated a very large amount of material compared to their annual river loads of sediment
\end{abstract}

\section{INTRODUCTION}

Floodplains and other riparian features are known to be important locations for sediment storage in fluvial systems (Phillips 1989; Steiger and others 2003). Large amounts of sediment eroded from post-colonial agriculture in the US, and its associated nutrients, are thought to be stored in stream valleys (Meade 1982; Walters and Merritts 2008).

Received 8 December 2008; accepted 6 April 2009; published online 22 May 2009

Authors Contributions C.H. designed and implemented the sampling network. G.N. performed the chemical analyses of sediment, statistical analyses, and the scaling and retention analyses. G.N. wrote the article and both authors discussed the results and edited the manuscript.

*Corresponding author; e-mail: gnoe@usgs.gov (median among rivers $=119 \%)$, nitrogen $(24 \%)$, and phosphorus $(59 \%)$. Systems with larger floodplain areas and longer floodplain inundation retained greater proportions of riverine loads of nitrogen and phosphorus, but systems with larger riverine loads retained a smaller proportion of that load on floodplains. Although the source and longterm fate of deposited sediment and associated nutrients are uncertain, these fluxes represent the interception of large amounts of material that otherwise could have been exported downstream. Coastal Plain floodplain ecosystems are important regulators of sediment, carbon, and nutrient transport in watersheds of the Chesapeake Bay.

Key words: floodplain; sediment; nitrogen; phosphorus; retention; wetland; river.

The in-stream processes that entrain, transport, and store the sediment retained in stream valleys are important for understanding material transport in watersheds, as suggested by the inability of upland erosion rate estimates to predict current sediment yields in the mid-Atlantic region of the US (Boomer and others 2008). Although the literature contains abundant references to the buffering function of riparian areas (sediment and nutrient trapping from upland flow), particularly in headwaters (for example, National Research Council 2002), much less literature has been devoted to the retention function of floodplain ecosystems (trapping from flood flow). 
The storage of sediment in floodplains has consequences for the retention and cycling of nutrients and contaminants. Sedimentation has been appreciated as an important flux for phosphorus (P) in wetlands (Johnston 1991). Although denitrification has received considerable attention among nitrogen $(\mathrm{N})$ fluxes in floodplains, there is less recognition of the potentially large magnitude of $\mathrm{N}$ sedimentation fluxes (Olde Venterink and others 2006). Noe and Hupp (2005) reported high rates of $\mathrm{P}$ as well as carbon $(\mathrm{C})$ and $\mathrm{N}$ accumulation associated with floodplain sedimentation along Coastal Plain rivers. Large amounts of radioisotopes and trace metals also accumulate in association with sedimentation in floodplains (Hupp and others 1993; Malmon and others 2002).

Few quantitative estimates exist for the retention of river loads by floodplains at the scale of catchments or large river reaches. Here we provide estimates for plot-scale sediment and sedimentassociated $\mathrm{C}, \mathrm{N}$, and $\mathrm{P}$ accumulation rates in Coastal Plain floodplains located in the Chesapeake Bay watershed, USA. Plot-scale accumulation rates were first reported for three rivers in Noe and Hupp (2005); in this study we report rates for an additional four rivers. For these seven rivers, we then scale rates from individual plots to the entire extent of floodplain along their freshwater, non-tidal Coastal Plain reaches. Finally, we compare floodplain trapping to river loads to calculate the percent retention of river sediment, $\mathrm{N}$, and $\mathrm{P}$ loads by floodplains. We expected that rivers with larger floodplain area (size of sink), longer floodplain inundation (river to floodplain exchange), and larger river loads (size of source) had greater proportions of their loads retained by floodplains.

\section{Methods}

\section{Site Description}

Sediment deposition rates were measured at multiple sites along the freshwater Coastal Plain reaches of seven rivers in the Chesapeake Bay watershed (Figure 1; see Gellis and others 2008, for more details). These rivers were chosen because they have relatively broad, forested floodplains characteristic of riverine wetlands on the Atlantic and Gulf Coastal Plains. Other major Chesapeake Bay tributaries (Susquehanna, Potomac, James, Rappahannock, and York Rivers) are embayed to the Fall Line and do not support large areas of forested bottomlands (Hupp 2000), although their

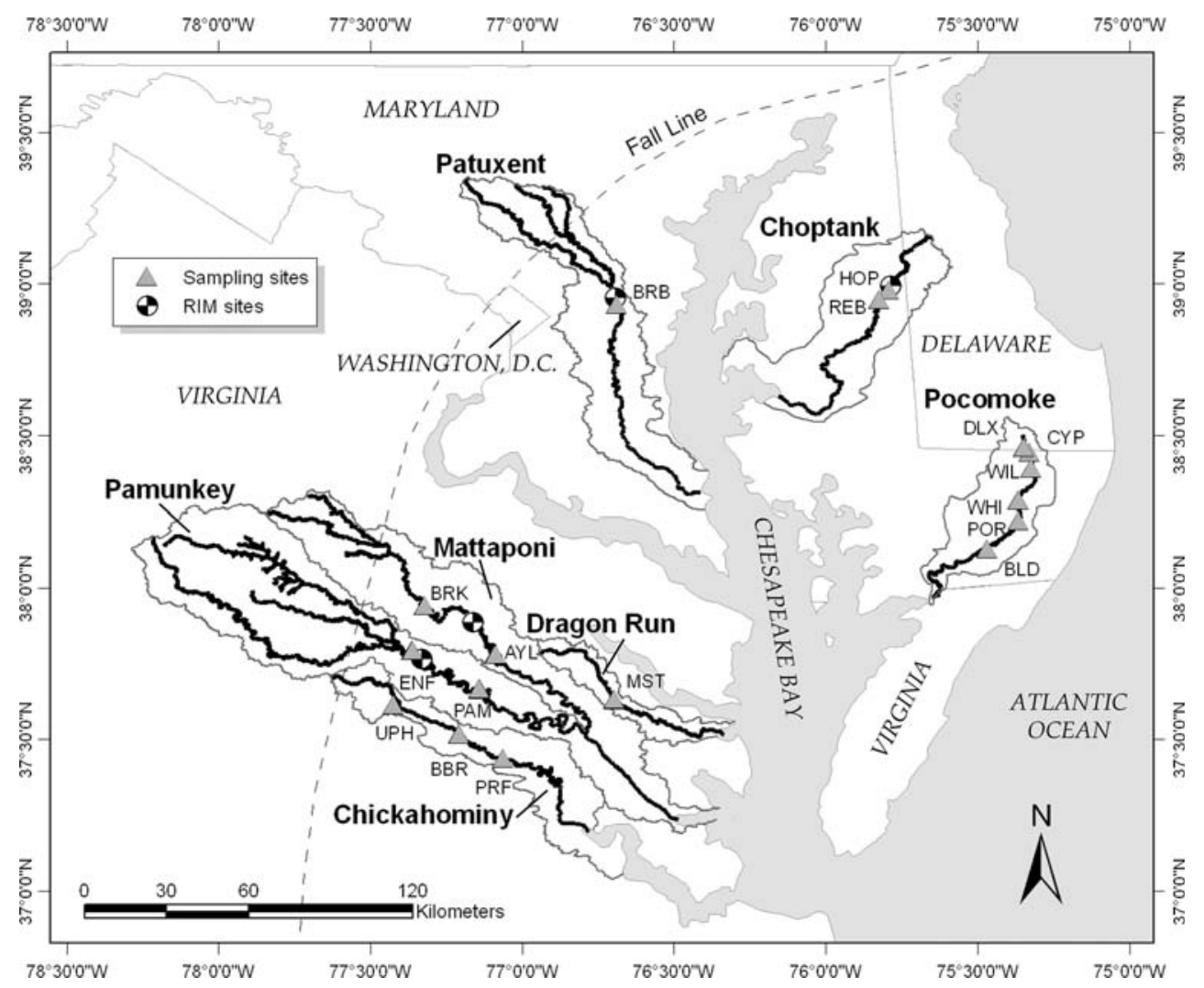

Figure 1. Watershed maps of the seven rivers included in this study with the locations of sampling sites and river input monitoring (RIM) sites. 
tributaries may have well-developed floodplains. Study sites (1-6 sites per river) were selected to be relatively easily accessed by road, support contiguous mature bottomland forest, generally experience hydroperiods typical of Coastal Plain rivers, and have minimal tidal influence at the most downstream site. Multiple floodplain transects (typically three) were established at each study site, oriented perpendicular to the river and separated by $50-100 \mathrm{~m}$, beginning on the channel edge (usually a natural levee) and continuing for a few hundred meters into the low backswamp area. Each transect typically had 4-6 monitoring plots where periodic measurements were made of sediment accretion rate and sediment texture and composition. This sampling design systematically encompassed all typical floodplain micro-topographic and vegetation features present at each floodplain site.

For each river, the duration of floodplain inundation over the period of sediment deposition measurements was estimated by calculating the number of days that river stage at the nearest gage was above the elevation of the floodplain soil surface (Table 1). The stage threshold for floodplain inundation was determined from observations of flooding at sites (Ross and others 2004) or either cross-sectional surveys of stream and floodplain topography (E. Doheney, USGS, personal communication) or the break in slope of the stage-discharge rating curve at the nearby river gage. These methods provide general estimates for the inundation of floodplain along a river but ignore interand intra-site variation in flooding due to variation in river stage and floodplain elevation.

\section{Sediment Accretion Rates}

An artificial marker horizon was created at each monitoring plot by placing powdered white feldspar clay to a depth of about $20 \mathrm{~mm}$ on about $0.5 \mathrm{~m}^{2}$ of soil surface that had been cleared of coarse organic detritus. The clay becomes a firm marker after absorption of soil moisture that permits accurate measurement of short-term net vertical accretion above the clay surface (Baumann and others 1984; Hupp and others 1993; Kleiss 1996). In general, the marker horizons were examined for depth of burial annually and at selected times after flooding events. Here we report accretion rates (change in depth; $\mathrm{m} \mathrm{y}^{-1}$ ) for the latest sampling dates when the largest number of marker horizons could be sampled for each site (Table 1). These periods of record were not concurrent for all rivers but ranged from 1996 to 2003. Depth of burial was measured by coring the ground surface and measuring the vertical depth of sediment above the marker horizon when surface water was not present. Sediment adjacent to the marker horizon was sampled to a depth corresponding to the depth of deposition and then analyzed for bulk density and percent organic matter (loss on ignition).

\section{Sediment and Nutrient Accumulation Rates}

Nutrient concentrations and mass accumulation rates (change in mass; $\mathrm{g} \mathrm{m}^{-2} \mathrm{y}^{-1}$ ) were directly measured at a subset of sites where sediment accretion was measured, along the Chickahominy, Mattaponi, and Pocomoke Rivers (Noe and Hupp 2005). Two to four replicate cores were collected above each marker horizon after coarse woody debris larger than $2 \mathrm{~mm}$ in diameter was removed from the coring location. The bulk accumulated sediment above each marker horizon was composited, transported to the laboratory, dried, ground, analyzed for TN and TC by elemental analysis (Carlo-Erba CHN analyzer), analyzed for TP by microwave-assisted acid $\left(\mathrm{HNO}_{3}, \mathrm{HCl}\right.$, and then HF) digestion and analysis on an ICP-OES (Perkin-Elmer), and analyzed for organic content by combustion at $400^{\circ} \mathrm{C}$ for $16 \mathrm{~h}$ (Noe and Hupp 2005). Preliminary analyses indicated that inorganic C was a negligible proportion of TC. In addition, we collected soil cores above marker horizons along the Coastal Plain floodplain of the Piedmont-dominated, alluvial Roanoke River in North Carolina (Hupp and others 2009). The data from the Roanoke River floodplain was included to develop a more general database of floodplain sediment characteristics that was used to parameterize regressions predicting soil nutrient concentrations at additional sites (see below). As with sediment accretion rates, nutrient and sediment accumulation rates measured this way represent net rates over the duration of marker-horizon deployment (see Noe and Hupp 2005).

Here we extend the accumulation rate estimates to more sites along the seven rivers where only sediment accretion was measured. This extension was accomplished for sediment accumulation rates using measured sediment bulk density at each site, measured vertical accretion rates at each plot, and known ages of marker-horizon deployment (Equation 1), and for nutrient accumulation rates 


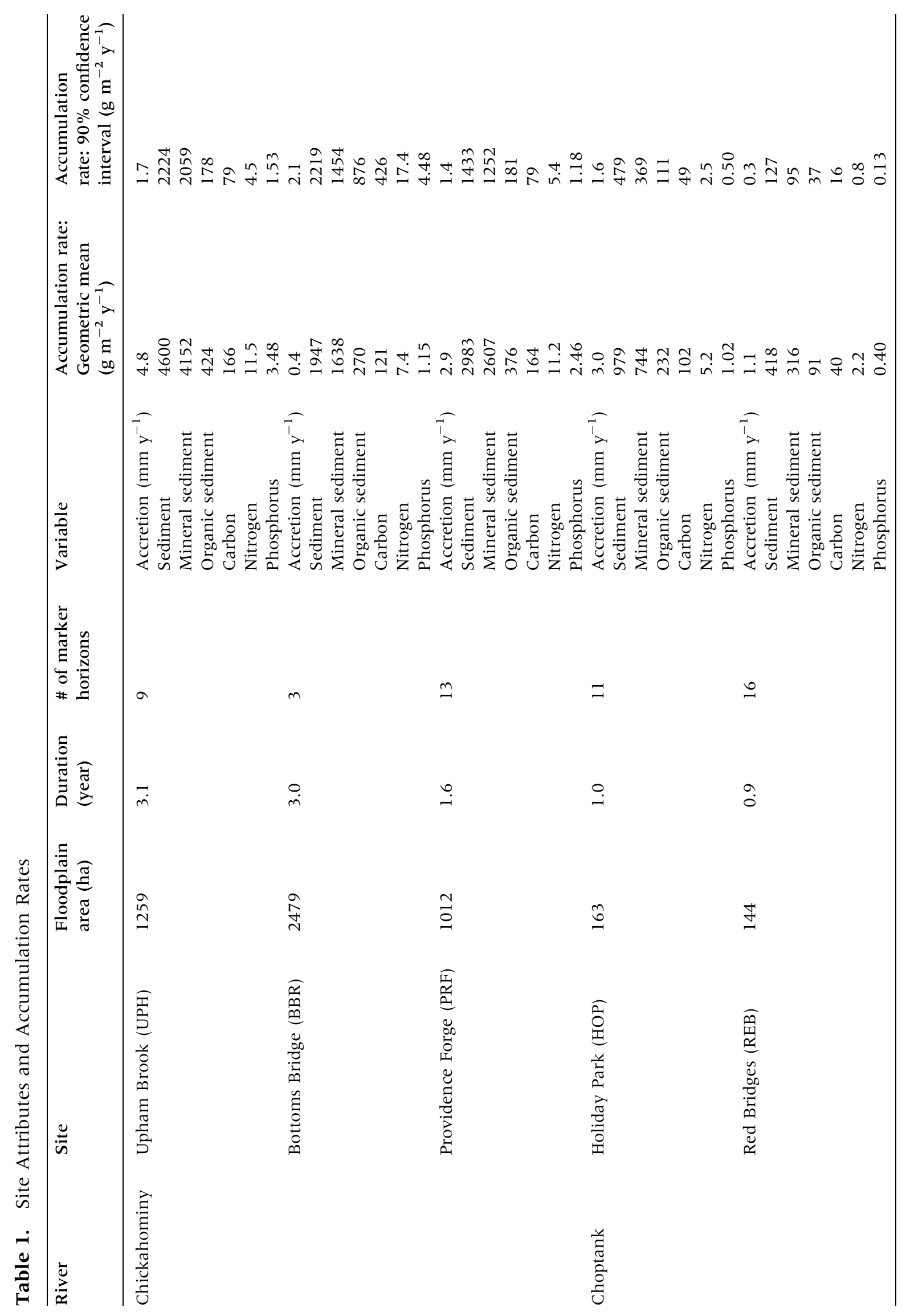




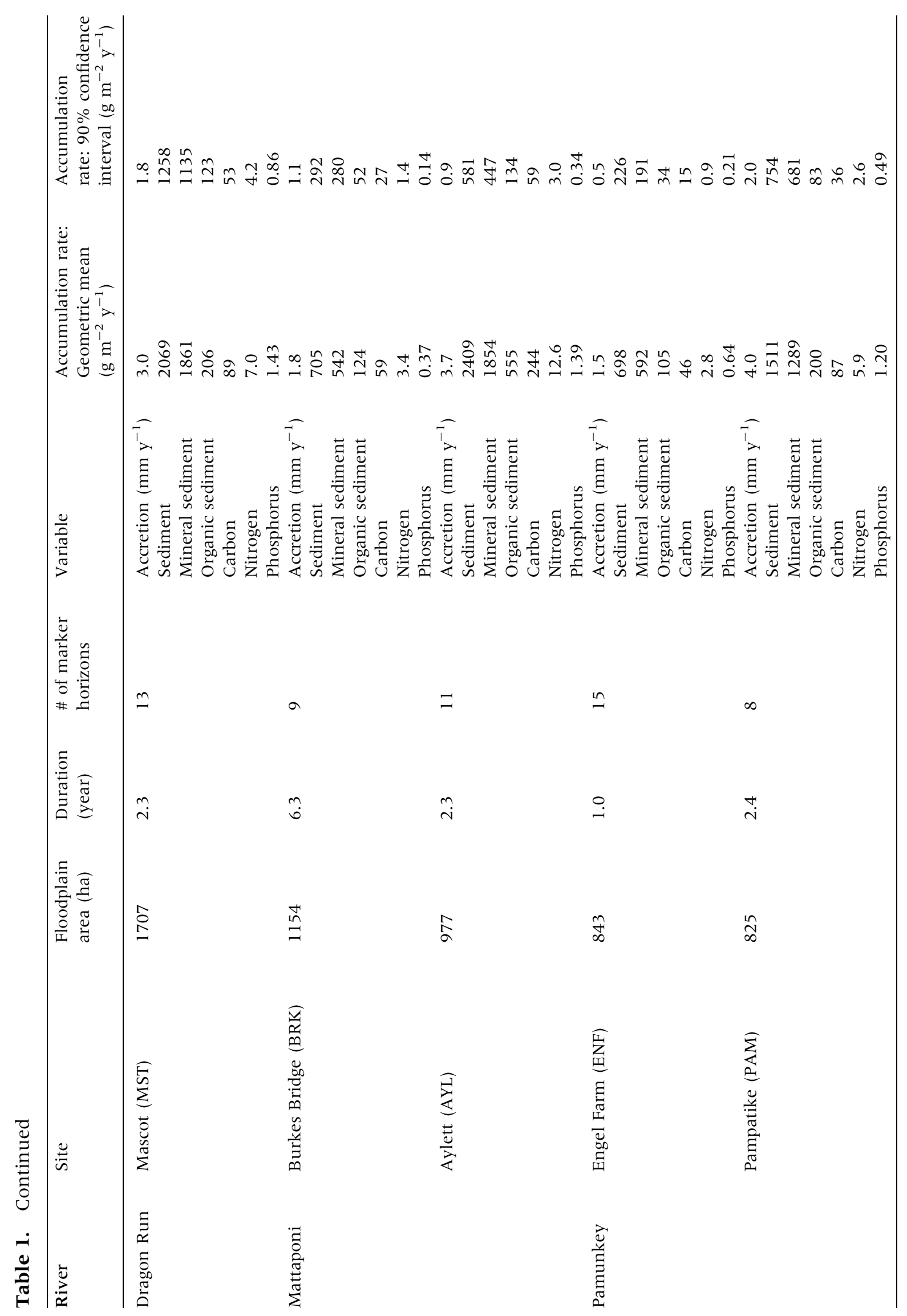




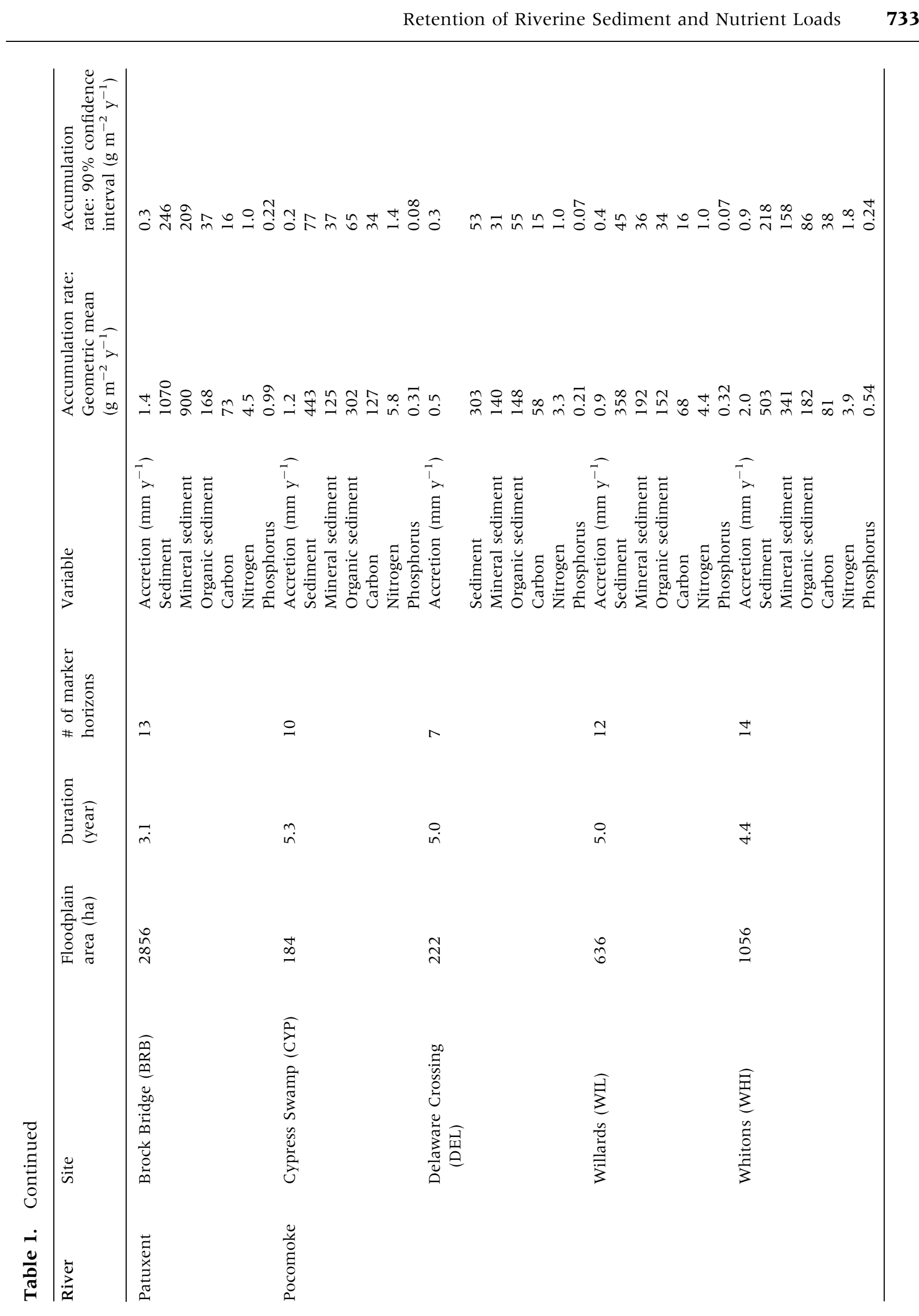




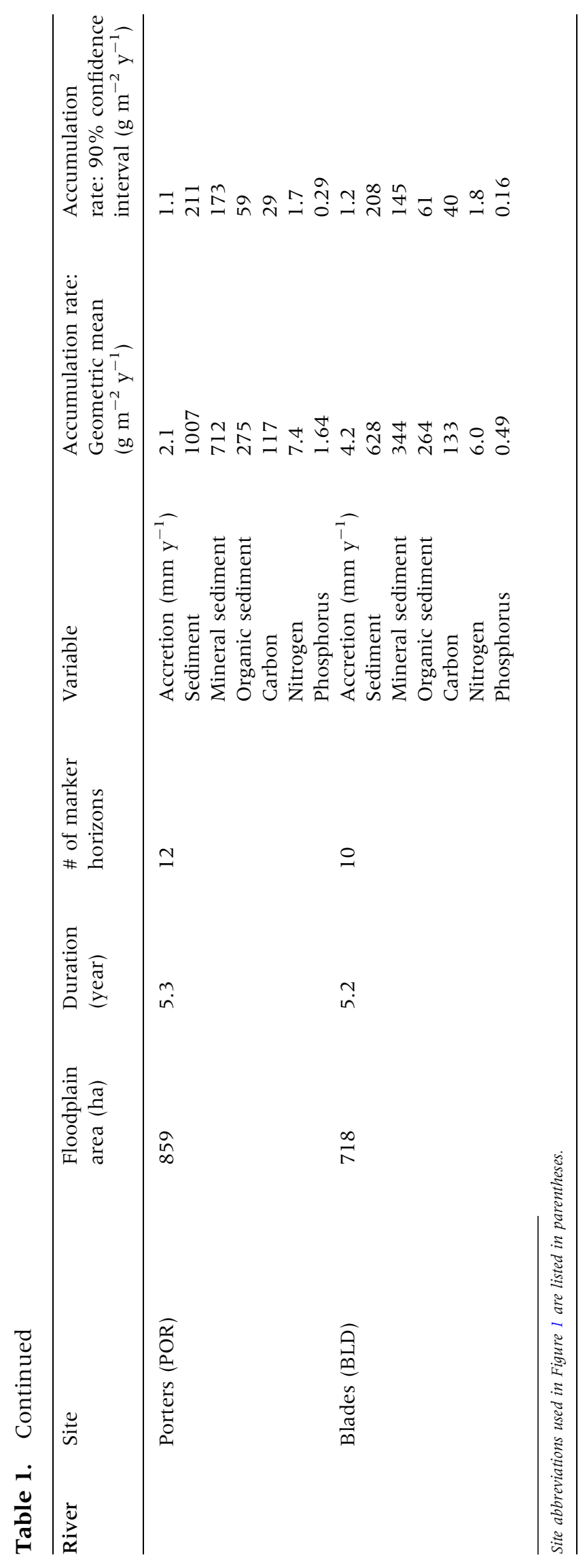


using sediment accumulation rates and predicted sediment $\mathrm{C}, \mathrm{N}$, or $\mathrm{P}$ concentrations (Equation 2):

Sediment accumulation rate $=$

(accretion; $\mathrm{m} \mathrm{y}^{-1}$ ) $*$ (bulk density; $\mathrm{g} \mathrm{m}^{-3}$ )

$/($ age $; y)=\mathrm{g} \mathrm{m}^{-2} \mathrm{y}^{-1}$

Nutrient accumulation rate $=$

(sediment accumulation rate; $\mathrm{g} \mathrm{m}^{-2} \mathrm{y}^{-1}$ )

* (predicted C, N, or P concentration; $\mathrm{gg}^{-1}$ )

$=\mathrm{g} \mathrm{m}^{-2} \mathrm{y}^{-1}$

We parameterized regressions to predict sediment TC, TN, and TP from sediment organic matter concentration using log-transformed data from the four rivers where this information was directly measured $(n=96$ marker horizons from the Chickahominy, Mattaponi, Pocomoke, and Roanoke Rivers). We then used these regressions to predict $\mathrm{C}, \mathrm{N}$, and $\mathrm{P}$ concentrations in sediments from sites that have not been analyzed for nutrients but had measured organic matter concentrations. Directly measured sediment and nutrient accumulation rates $(n=72)$, when available, were used in preference to rates estimated from accretion rates $(n=114)$. For each floodplain site, the geometric mean and an estimate of uncertainty $( \pm 90 \%$ confidence limits (CL)) were calculated for sediment accretion and for sediment, C, N, and P accumulation rates. Because these statistics were calculated from measurements at the multiple marker horizons within each site, they encompass the hydrogeomorphic and vegetation variation inherent in these floodplain ecosystems.

\section{Scaling}

Estimates were made of the floodplain area of the non-tidal Coastal Plain reach of each river, defined as the riparian area extending from the Fall Line to the upper limit of tidal influence. The limit of tidal influence was assumed to be $1 \mathrm{~km}$ below the most downstream sampling location on each river. The Patuxent and Choptank Rivers each had one site located downstream from the sites included in this study, located near the limit of tidal influence, which could not be included in this study due to the lack of sediment organic content and bulk density information. Accretion rates at this most downstream Patuxent River site were twice those measured at the single Patuxent River floodplain site included here (Gellis and others 2008), resulting in an underestimation of sediment and nutrient accumulation rates for the Patuxent River floodplain in this study. Site-scale estimates of floodplain mean accumulation rates were then extrapolated to the entire non-tidal, freshwater Coastal Plain reach of each river using these estimates of floodplain area.

Topographic maps (USGS 1:24,000) and digital mapping software (Garmin Mapsource) were used to determine floodplain length and width. For rivers with more than one floodplain site, the river was divided into segments defined by channel midpoints between sites. Length of floodplain for each river segment was measured as thalweg distance. The width of each floodplain segment was estimated as the mean of 10 measurement transects per segment. Floodplain width on both sides of the river was defined from the river bank to the base of the valley slope when it was clearly defined by 5 or $10 \mathrm{ft}$ contour lines or up to the edge of the wetland delineated by the cartographers. Floodplain-width estimates were narrowed when a road or structure would limit hydrologic connectivity with backswamps. The product of the site accumulation rate and segment floodplain area for each site was summed for each river to generate floodplain trapping $\left(\mathrm{g} \mathrm{Y}^{-1}\right)$ for each parameter (sediment, $\mathrm{C}$, $\mathrm{N}$, and $\mathrm{P}$ ). This summation was done independently for mean, $+90 \%$ CL, and $-90 \%$ CL accumulation rates, with the confidence intervals representing the variation expected along that river as extrapolated from the depositional variation within each floodplain site.

\section{River Loads}

Riverine loads $\left(\mathrm{g} \mathrm{y}^{-1}\right)$ of sediment, total $\mathrm{N}$, and total $\mathrm{P}$ are measured near the Fall Line of the larger rivers in the Chesapeake Bay watershed, including the Mattaponi, Pamunkey, and Patuxent Rivers, as well as above the limit of tidal influence on the Choptank River, as part of the USGS River Input Monitoring Program (RIM; Langland and others 2006). Annual loads of sediment, but not nutrients, were also measured on the Pocomoke River at the Willards site (Gellis and others 2008). The locations of these river load measurements are upstream or nearby the most upstream of the floodplain sites along each river, with the exception of the two most upstream sites along the Pocomoke River which are disconnected from the river (Noe and Hupp 2005) and the most upstream site along the Mattaponi River (Figure 1). The annual loads for each of these rivers were averaged over the years spanning the dates of marker-horizon installation 
and final measurement of sediment deposition. Annual loads of sediment were not measured on the Chickahominy and Dragon Run Rivers. Average annual TN and TP loads for the Chickahominy, Dragon Run, and Pocomoke Rivers were estimated for their Coastal Plain reaches from output of the steady-state SPARROW watershed model (Alexander and others 2008).

\section{Retention}

Because river loads were primarily estimated at locations upstream of the floodplain reaches, percent retention of the annual riverine load by floodplains was calculated as the total floodplain trapping rate along a river divided by the annual load of that river. We also provide alternative retention estimates calculated as floodplain trapping divided by the sum of river load and floodplain trapping, which underestimates retention in this study because each of the seven rivers had floodplains located downstream of the river load estimate. Retention was calculated for sediment, $\mathrm{TN}$, and TP using geometric mean, $+90 \% \mathrm{CL}$, and $-90 \%$ CL accumulation rates. The relative importance of river floodplain area, floodplain inundation, and river load for controlling riverine floodplain retention of sediment, TN, and TP was evaluated using Pearson product-moment correlations on log-log transformed data. Because floodplain area and river load are used to calculate percent retention, the statistics are spurious but the correlation coefficients represent a test of the sensitivity of each term in determining percent retention.

\section{RESUlts}

\section{Extrapolating Nutrient Concentration Data}

Concentrations of $\mathrm{TC}$ and $\mathrm{TN}$ in accumulating floodplain sediments were well predicted by the organic content of the sediment (Figure 2; linear regression with $\log -\log$ transformation; $n=96$; TC: $R^{2}=0.937, P<0.001 ; \mathrm{TN}: R^{2}=0.888, P<$ $0.001)$. Sediment TP concentrations were less precisely predicted by organic content (quadratic regression with $\log -\log$ transformation; $R^{2}=$ $0.236, P<0.001)$, as expected given the importance of mineral sediment geochemistry for controlling $\mathrm{P}$ content. However, residuals of predicted TP were largely unbiased by the river of sample collection.
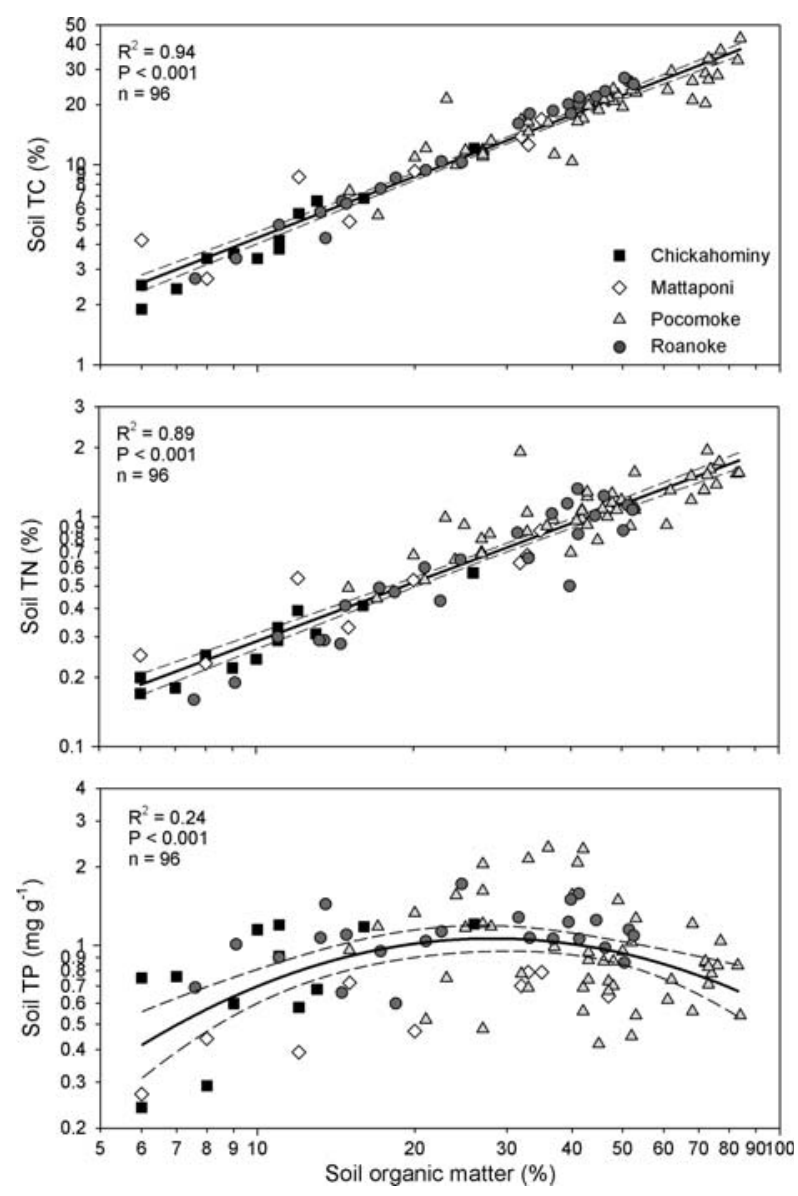

Figure 2. Relationships between organic content and total carbon (TC), nitrogen (TN), and phosphorus (TP) concentrations for recently deposited floodplain sediments along four different rivers. Linear (TC and TN) and quadratic (TP) regressions of $\log -\log$ transformed data were used to predict sediment nutrient concentrations at sites where only sediment organic content was measured. Solid lines show predicted concentrations and dashed lines show $95 \%$ confidence intervals of those predictions.

\section{Sediment Accretion and Nutrient and Sediment Accumulation Rates}

The vertical accretion of sediment varied widely among different floodplain sites. Accretion rates ranged from 0.4 to $4.8 \mathrm{~mm} \mathrm{y}^{-1}$ among sites (within-site geometric means, Table 1), with a grand geometric mean of $1.8 \mathrm{~mm} \mathrm{y}^{-1}$ for the 17 sites located around the Chesapeake watershed. Sediment accumulation rates ranged from 303 to $4,600 \mathrm{~g} \mathrm{~m}^{-2} \mathrm{y}^{-1}$, with a geometric mean of $976 \mathrm{~g} \mathrm{~m}^{-2} \mathrm{y}^{-1}$. Average $\mathrm{P}$ accumulation rates ranged from 0.21 to $3.48 \mathrm{~g} \mathrm{~m}^{-2} \mathrm{y}^{-1}$ among sites, with a geometric mean of $0.79 \mathrm{~g} \mathrm{~m}^{-2} \mathrm{y}^{-1}$. Carbon accumulation rates were less variable among sites 
than sediment accumulation rates, ranging from 40 to $244 \mathrm{~g} \mathrm{~m}^{-2} \mathrm{y}^{-1}$, with a geometric mean of $93 \mathrm{~g} \mathrm{~m}^{-2} \mathrm{y}^{-1}$. Similarly, $\mathrm{N}$ accumulation rates were relatively less variable among sites, ranging from 2.2 to $12.6 \mathrm{~g} \mathrm{~m}^{-2} \mathrm{y}^{-1}$, with a geometric mean of $5.5 \mathrm{~g} \mathrm{~m}^{-2} \mathrm{y}^{-1}$. In addition to the variation in accretion and accumulation rates among the 17 sites, variation within individual floodplain sites was sometimes large as shown by the $90 \%$ confidence intervals of each rate (Table 1).

Scaling these sediment and nutrient accumulation rates to the entire non-tidal Coastal Plain reach of each river was calculated using floodplain area along each river. Floodplain area along the Coastal Plain reaches ranged from 307 to 4,749 ha among rivers (Table 2). Floodplain inundation was estimated to occur from 7 to $52 \%$ of the days during the period of measurement in each river. Mean annual cumulative sediment trapping on floodplains ranged from 2.2 to $136 \mathrm{Gg} \mathrm{y}^{-1}$ among rivers, $\mathrm{C}$ trapping ranged from 224 to $6732 \mathrm{Mg} \mathrm{y}^{-1}, \mathrm{~N}$ trapping ranged from 11.7 to $442 \mathrm{Mg} \mathrm{Y}^{-1}$, and $\mathrm{P}$ trapping ranged from 2.2 to $97.2 \mathrm{Mg} \mathrm{Y}^{-1}$.

\section{River Loads}

Mean annual river loads for all parameters were not available for all the rivers in this study. Carbon loads, in particular, were not available for any river, and sediment loads were not available for the Chickahominy River and Dragon Run. The mean annual river load, which was estimated over the duration of each river's marker-horizon deployments, varied widely among rivers. Sediment loads ranged from 2.8 to $60.3 \mathrm{Gg} \mathrm{y}^{-1}$, $\mathrm{N}$ load ranged from 76.7 to $1,039 \mathrm{Mg} \mathrm{Y}^{-1}$, and $\mathrm{P}$ load ranged from 4.1 to $106 \mathrm{Mg} \mathrm{Y}^{-1}$ (Table 2).

\section{Percent Retention}

The amount of sediment and nutrients accumulating on floodplain surfaces was often a high proportion of each river's annual load, with percent retention values increasing from $\mathrm{N}$ to $\mathrm{P}$ to sediment. Sediment accumulating on the Coastal Plain floodplains represented from $30 \%$ to $690 \%$ of river sediment loads, with a median value among rivers of $119 \%$ (Table 2). For N, sediment accumulating on floodplain surfaces constituted $4 \%$ to $156 \%$ of river $\mathrm{N}$ loads, with a median of $24 \%$. Phosphorus accumulation on floodplains ranged from $14 \%$ to $604 \%$ of river $\mathrm{P}$ loads, with a median of $59 \%$. When rivers with only measured loads of sediment or nutrients were considered and SPARROW predicted loads were excluded, median retention of riverine sediment, $\mathrm{N}$, and $\mathrm{P}$ loads by floodplains were 119,12 , and 38\%, respectively (Table 2). Using an alternative calculation of retention that includes floodplain trapping along with measured or predicted river load for determining total load, floodplain sediment retention ranged from 23 to $87 \%($ median $=54 \%), \mathrm{N}$ retention ranged from 4 to $61 \%$ (median $=19 \%$ ), and $\mathrm{P}$ retention ranged from 13 to $86 \%$ (median $=37 \%$ ).

These estimates represent the geometric mean floodplain accumulation rates along rivers. Upper and lower $90 \%$ confidence limits on site accumulation rates were large when translated to percent retention of river loads. As examples, the rivers that represented the median percent retention among rivers had confidence limits that ranged from 94 to $149 \%$ retention of the sediment load (Patuxent River), 18 to $32 \%$ retention of the $\mathrm{N}$ load (Pocomoke River), and 47 to $74 \%$ of the $\mathrm{P}$ load ( $\mathrm{Pa}$ tuxent River; Table 2).

The relative importance of the river load, floodplain area, and floodplain inundation for controlling percent retention rates among rivers was tested by comparing their correlation coefficients. Neither sediment, $\mathrm{N}$, or $\mathrm{P}$ percent retention were significantly correlated with river loads, floodplain area, or floodplain inundation $(P>0.065)$, in part due to low statistical power. Sediment percent retention rates were positively associated with floodplain inundation $(n=5, r=0.552)$ and floodplain area $(r=0.459)$, and negatively associated with river sediment load $(r=-0.627)$. Phosphorus percent retention rates were also positively associated with floodplain inundation $(n=7, r=0.726)$ and floodplain area $(r=0.456)$ and negatively associated with river TP load $(r=-0.583)$. Finally, percent $\mathrm{N}$ retention was also positively associated with floodplain inundation $(n=7, r=0.598)$ and floodplain area $(r=0.608)$ and negatively associated with river TN load $(r=-0.552)$.

\section{Discussion}

\section{Comparison of Load Retention Among Floodplains}

Floodplains represent an important location for nutrient and sediment retention in fluvial landscapes. Headwater streams are known to be important regulators of downstream $\mathrm{N}$ loads during mean flow conditions (Alexander and others 2007). Extensive riparian ecosystems in headwaters also directly intercept large amounts of sediments and nutrients transported from adjacent uplands (Brinson 1988, National Research Council 2002). However, most downstream loading of 


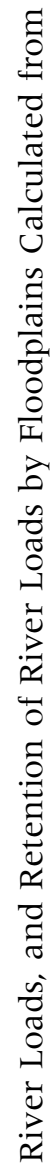

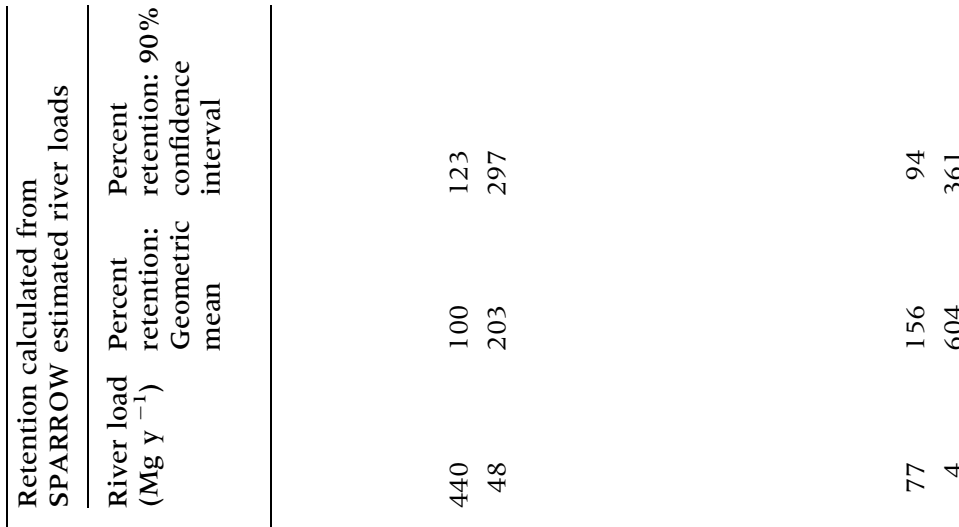

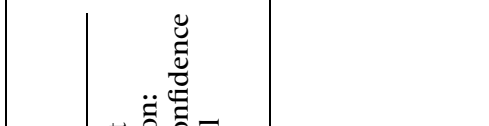

$\overrightarrow{0}$

$\frac{8}{8}$

$+$

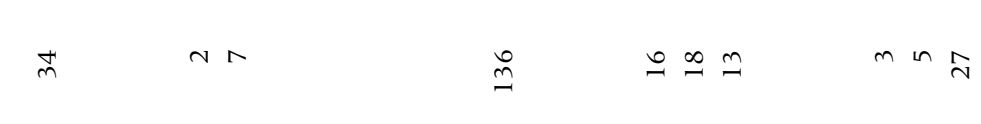

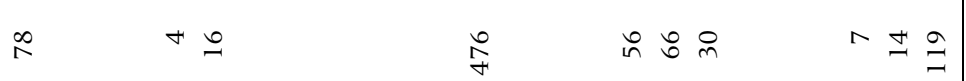

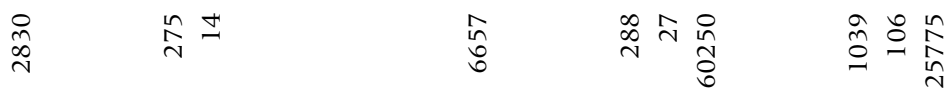

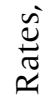

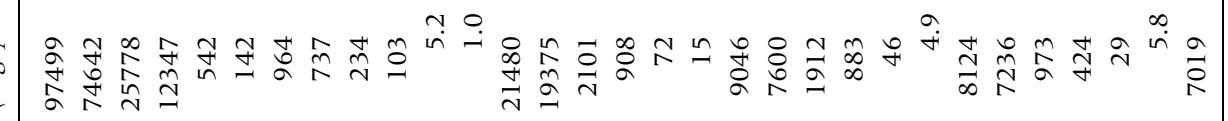

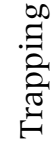

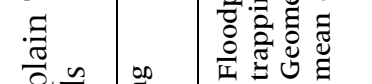

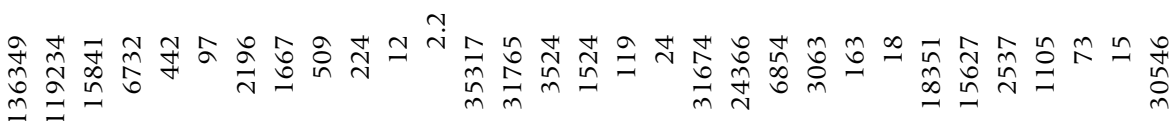

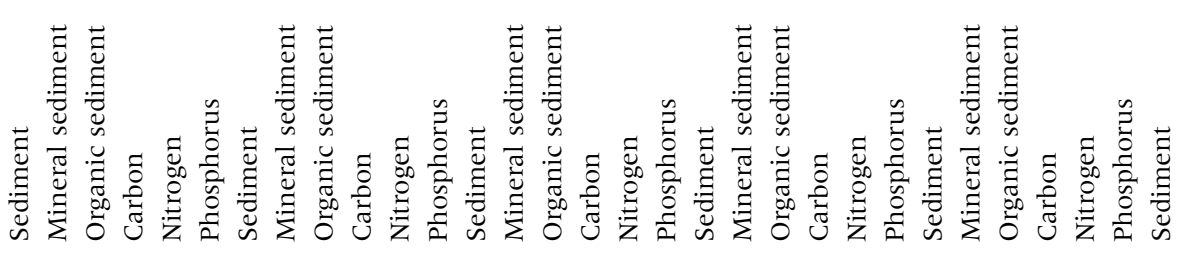

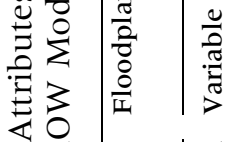

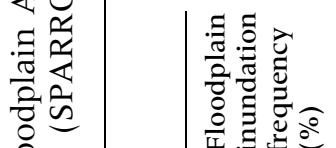

II

శृ

के

幽

ำ

不.

$\vec{\sim}$

$\geq$

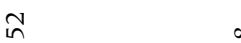

ò

$\stackrel{2}{\subseteq}$

$\stackrel{\sim}{\sim}$

\begin{tabular}{l}
$\infty$ \\
$\stackrel{0}{\circ}$ \\
\hdashline
\end{tabular}

i̊

है
हैँ
ป

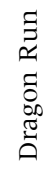

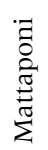

气

葡 


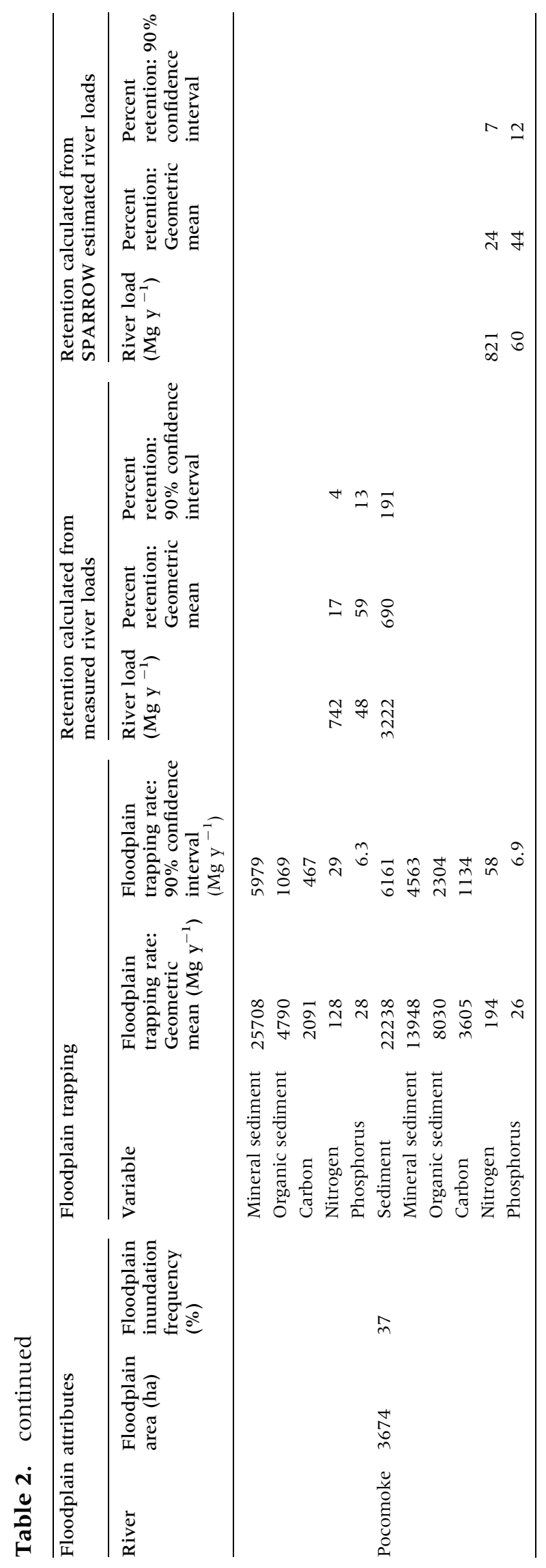


sediment and $\mathrm{P}$, and a large amount of $\mathrm{N}$, occurs during high-discharge events when floodplains can be hydraulically connected to the main river channel (Meade 1982; House and others 1997; Brunet and Astin 2000; Royer and others 2006; Scott and others, unpublished). Subsurface exchange between lower-order streams and their hyporheic zone is limited during these times of elevated discharge (Harvey and Wagner 2000). The high nutrient and sediment accumulation rates in the floodplains along the rivers in this study suggest that the location of biogeochemical hotspots moves downstream from headwaters to inundated floodplains during high-flow events (that is, hot moments, McClain and others 2003).

Nutrient and sediment annual accumulation rates per unit area associated with sediment deposition in the non-tidal, Coastal Plain floodplains of this study were in the middle of the ranges measured in other floodplains (Johnston 1991; Kleiss 1996; Walling and others 1999; Craft and Casey 2000; Olde Venterink and others 2006). The role of $\mathrm{N}$ retention through sedimentation is less frequently quantified than denitrification, although their magnitudes can be comparable (Olde Venterink and others 2006). However, nitrate removal rates through denitrification are roughly five times greater in riverine wetlands in the Mississippi River watershed, which has high nitrate loading (Mitsch and others 2005), than the mean $\mathrm{N}$ accumulation rates via sedimentation in this study. Models and studies of floodplain removal of $\mathrm{N}$ from riverine water should consider both denitrification and sedimentation fluxes, particularly in watersheds with a larger proportion of the TN load in particulate forms.

The non-tidal floodplains of the Chesapeake Coastal Plain also accumulated large amounts of C. Identification of these $\mathrm{C}$ sequestration rates by riverine wetlands fills a large unknown in models of wetland and biosphere $\mathrm{C}$ budgets (Bridgham and others 2006). Bridgham and others (2006) estimated a geometric mean $\mathrm{C}$ sequestration rate of $17 \mathrm{~g} \mathrm{C} \mathrm{m}^{-2} \mathrm{y}^{-1}$ from the few studies that have measured these fluxes in freshwater wetlands with mineral soils, compared to $93 \mathrm{~g} \mathrm{C} \mathrm{m}^{-2} \mathrm{y}^{-1}$ among the floodplain sites in this study. Hupp and others (2008) also documented large amounts of C trapping by the Atchafalaya River Basin of Louisiana, USA. That study and this study suggest that floodplains along Coastal Plain rivers are important regulators of riverine and global $\mathrm{C}$ fluxes. Longterm storage of $\mathrm{C}$ in floodplains also can explain the old age of riverine particulate $\mathrm{C}$ exported to oceans (Raymond and Bauer 2001).
The rates of riverine sediment, $\mathrm{P}$, and $\mathrm{N}$ load retention by the floodplains along the Coastal Plain reaches of the seven Chesapeake rivers in this study were mostly higher compared to floodplain retention for other rivers. Although the lower percent retentions among the seven rivers were similar to other studies that calculated retention (in many different ways), the median values for rivers in this study were often twice as great for $\mathrm{N}, \mathrm{P}$, and sediment (Table 3). The median retention of annual river $\mathrm{N}$ load was $24 \%$ among the seven rivers (range $=4-156 \%)$, which exceeded all but one other study (also a large, Coastal Plain floodplain system, the Atchafalaya River Basin, Xu 2006) of annual $\mathrm{N}$ retention rates by floodplains (Table 3 ). The median annual $\mathrm{P}$ retention of $59 \%$ (range $=14-604 \%)$ was greater than all similar studies (Table 3), although higher $\mathrm{P}$ retention has been observed during periods of flooding. The median sediment retention of $119 \%$ (range $=30$ $690 \%$ ) also exceeds all other studies (Table 3). We believe that calculating retention as floodplain trapping divided by river load is the optimal method for our study design where load was measured near the upstream limit of the active floodplain reaches for all but one river. However, the alternative calculation of retention that includes floodplain trapping in the denominator, accounting for floodplain trapping upstream of the load measurements, also results in greater sediment, $\mathrm{N}$, and $\mathrm{P}$ retention by floodplains than most other studies. Finally, the median percent retention of river $\mathrm{N}$ and $\mathrm{P}$ loads by these floodplains in the Chesapeake Bay watershed was slightly less than the long-term mean percent of river loads associated with particulate nitrogen and ammonia $(28 \%)$ and particulate phosphorus (79\%) throughout the Chesapeake Bay watershed (Langland and others 2006), suggesting that these floodplains may capture most of the sediment-associated load of nutrients if additional sources of loading in the Coastal Plain were not present (see "Uncertainty and Assumptions", below).

\section{Controls on Retention}

Both floodplain area and river load were used to calculate percent retention, but comparison of their correlations with percent retention, as well as that of floodplain inundation, suggests the sensitivity of each term in controlling retention. The absolute values of the correlation coefficients were generally similar among floodplain area, floodplain inundation, and river load for sediment, $\mathrm{N}$, and $\mathrm{P}$ percent retention. Sediment retention was mostly strongly 


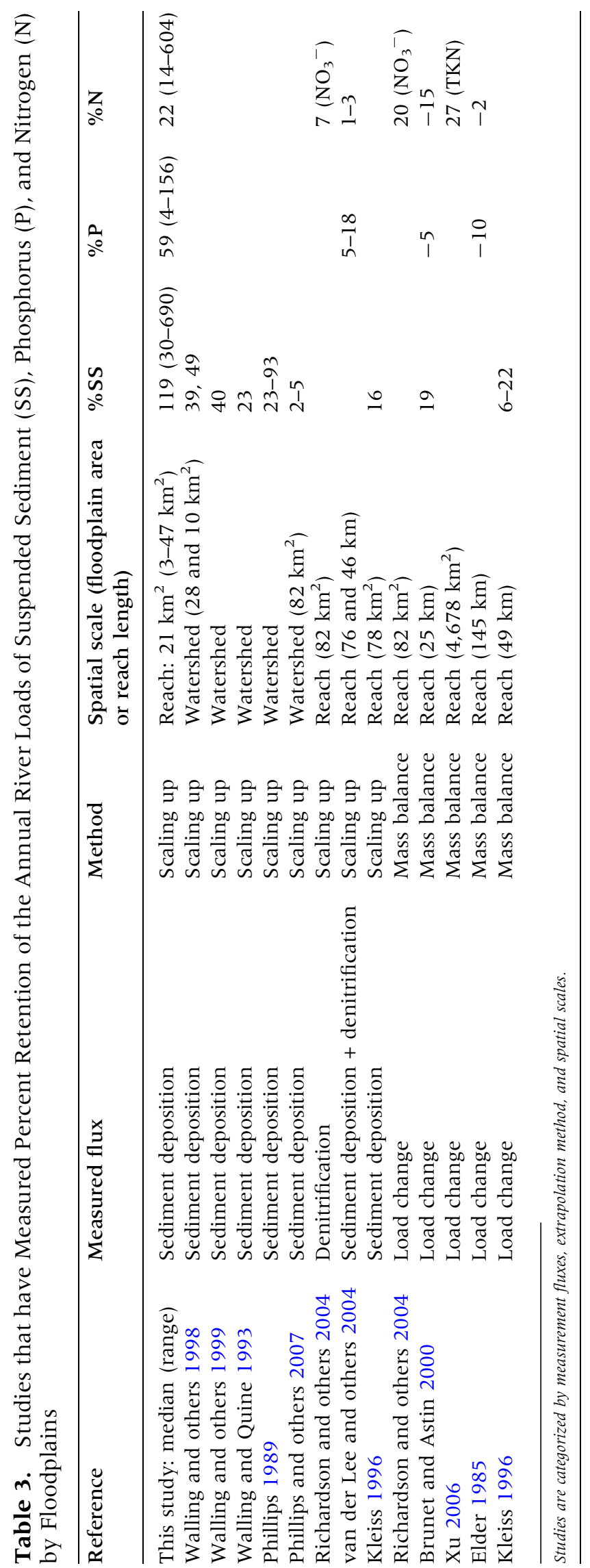


associated with river sediment load, whereas $\mathrm{P}$ retention was most strongly associated with floodplain inundation, and $\mathrm{N}$ retention with floodplain area. However, percent retention of sediment, N, and $\mathrm{P}$ were each positively related to floodplain area and floodplain inundation but negatively related to river loads. Rivers with larger material sinks (more floodplain area) had greater proportional interception of riverine loads by floodplains than average. The larger floodplain areas likely decreased velocity and increased hydraulic residence times of floodwaters before re-entering the main channel, resulting in more floodplain deposition. In addition, rivers with floodplains that were inundated more often (greater connectivity) had greater proportional retention of river loads, likely due to greater opportunity for material transport from river to floodplain. In contrast, rivers with larger material sources (larger river loads) had less proportional interception of those riverine loads by floodplains than average. Larger river loads of sediment and nutrients were not compensated for by greater floodplain retention, suggesting an upward limit on the ability of floodplains to intercept and store sediment and nutrients at a watershed scale. Relatively larger river loads apparently bypass floodplains thereby limiting their capacity to retain larger proportions of those river loads, perhaps due to limitations on the amount of river water exchanged with floodplains. Alternatively, larger river loads may be associated with proportionally greater dissolved nutrient fractions that are less associated with removal by net sedimentation on floodplains. Nonetheless, the total mass of material trapped on floodplains increased with greater river loading rates.

Hydrologic connectivity between river and floodplain controls organic matter and nutrient exchange and retention by floodplains (Tockner and others 1999). The Coastal Plain reaches of the rivers in this study have more opportunity for floodplain-channel interactions than higher gradient systems. Bankfull discharge occurs roughly 7-8 times more frequently in Coastal Plain rivers compared to other Piedmont or mountain rivers (Sweet and Geratz 2003). Floodplains in this study were inundated from 7 to $52 \%$ of the days over their period of measurement, with a median of $17 \%$ among rivers (Table 1 ). In addition, the broad valleys of Coastal Plain rivers have large areas of floodplain that slow water velocity and have a high potential for settling of suspended sediment (Phillips 1989; Hupp 2000). The long residence time of floodwaters relative to biogeochemical uptake rates can result in near-complete removal of nutrients from floodplain waters, resulting in limitation of material retention in Coastal Plain floodplains by channel-floodplain exchange (for example, N; Scott and others, unpublished). Sediment accumulation rates in floodplains also are greater in lower reaches compared to other locations in watersheds (Walling and others 1998). The seven rivers in this study also had smaller annual river loads of sediment and nutrients compared to other studies that have quantified retention through sedimentation (Kleiss 1996; Walling and others 1999; van der Lee and others 2004; Phillips and others 2007). In summary, the relatively high rates of sediment and sediment-associated nutrient retention in the distal, Coastal Plain reaches of the rivers in our study were likely due to their hydrogeomorphic setting supporting high channelfloodplain connectivity, large floodplain area, slow water velocity, and small river loads.

\section{Uncertainty and Assumptions}

Percent retention estimates sometimes exceeded $100 \%$, especially for sediment, indicating that the retention estimates must be biased upwards compared to true floodplain retention of river loads. Several issues related to scaling our measurements from plots to reaches add uncertainty to our estimates of retention. First, we could not achieve a random selection of sites for measurements although sites were typical of Coastal Plain floodplains in the Chesapeake Bay watershed. Some rivers were sampled at only a limited number of sites. However, multiple transects and markerhorizons were placed within sites using a stratified random strategy that limited bias due to plot selection but encompassed the heterogeneity of the floodplains. We used this spatial variation in hydrogeomorphology and vegetation within sites to estimate uncertainty in accumulation rates and the resulting scaled retention estimates. The 90\% confidence intervals of percent retention were typically less than half of the magnitude of the mean estimate (Table 2). Second, the area of floodplain that actively exchanged water with the main channel may not have been accurately determined by our mapping, but we believe we achieved a reasonable estimation of floodplain area relative to the scope of the present paper. Third, the rates of nutrient and sediment retention apply only to the time periods and durations ( $1-6$ years) of marker horizon deployment in this study, although we used river load estimates that were concurrent with marker horizon deployments. Fourth, error was introduced by predicting soil nutrient con- 
centrations from soil organic content at some sites where it was not directly measured, especially for $\mathrm{P}$ which was not as well predicted as $\mathrm{N}$. Other uncertainties relate to the permanency of the storage of accumulated sediment and sedimentassociated nutrients on floodplains, and the sources of sediment deposited on floodplains.

\section{River Loads}

The measurements of sediment and nutrient loads used in this analysis were made near the Fall Line of the rivers, largely above the Coastal Plain reaches where sedimentation was quantified. Loads are not measured downstream from our study reaches in the Coastal Plain. Any loading of sediment or nutrients from local streams or bed and bank erosion located in the Coastal Plain was not included, which suggests that our estimates of loading may be too low and that our estimates of floodplain retention may be too high. Uncertainty in the monitored loads was greater for suspended sediment than for nutrients; for example, the 95\% confidence interval of the annual loads of TSS, TN, and TP in the Mattaponi River during 1997 water year were $7.44 \pm 1.28 \mathrm{Gg} \mathrm{y}^{-1}, 338 \pm 17 \mathrm{Mg} \mathrm{y}^{-1}$, and $31.5 \pm 2.5 \mathrm{Mg} \mathrm{Y}^{-1}$, respectively (Langland and others 2006). Some rivers did not have empirical measurements of nutrient loads, in which case we used outputs from the steady-state USGS SPARROW watershed model. The SPARROW model has prediction errors of $55 \%$ for TN and $76 \%$ for TP loads (Alexander and others 2008). The discrepancies in load estimates were sometimes large for rivers where both monitored and modeled loads were available. For example, the mean annual load for the Mattaponi River predicted by the SPARROW model is $624 \mathrm{Mg} \mathrm{Y}^{-1}$ for $\mathrm{TN}$ and $46 \mathrm{Mg} \mathrm{Y}^{-1}$ for TP (R. Alexander, USGS, unpublished data), compared to the monitored loads of 288 and $27 \mathrm{Mg} \mathrm{Y}^{-1}$ of $\mathrm{TN}$ and $\mathrm{TP}$, respectively, over the duration of marker-horizon deployments in this study (Langland and others 2006, Table 2). The very high retention rates of $\mathrm{N}$ and $\mathrm{P}$ in the Dragon Run and Chickahominy River floodplains may be due to underestimation of their actual river loads by the SPARROW model.

\section{Riverine Source of Material}

We assumed that the material deposited on floodplain surfaces was derived from the river. Owens and Walling (2002) demonstrated that most modern sediment deposited on floodplains was ultimately derived from upland topsoils, but channel banks were also significant. Deposited sediment may also be derived from re-suspension of upstream floodplain material as well as channel beds; retention time on floodplains is notoriously difficult to estimate. Riparian zones are known to be effective traps for sediment and nutrients transported directly from uplands (National Research Council 2002). Although agriculture is common in the adjacent uplands of the midAtlantic Coastal Plain, the wide floodplain valleys of the rivers in this study are unlikely to receive a large proportion of deposited sediment derived from upland erosion.

Organic sediment is more likely derived from autochthonous sources than mineral sediment in floodplains. Average litterfall rates (Clawson and others 2001) and leaf decomposition rates (Lockaby and Walbridge 1998) in forested wetlands of the southeastern United States would result in the accumulation of $100 \mathrm{~g} \mathrm{~m}^{-2} \mathrm{y}^{-1}$ of refractory organic sediment over the average 3.0 years of annual deposition increments for marker-horizon deployments in this study. This autochthonous production and decomposition of organic sediment is half the amount of organic sediment accumulation typically observed on floodplains in this study $\left(\right.$ median $\left.=206 \mathrm{~g} \mathrm{~m}^{-2} \mathrm{y}^{-1}\right)$, although one site had organic accumulation rates less than $100 \mathrm{~g} \mathrm{~m}^{-2} \mathrm{y}^{-1}$. Although the export of organic matter from floodplains is thought to provide a large energy subsidy to river channel food webs (Junk and others 1989), these estimates suggest that more than half of the organic matter deposited in these floodplains comes from the river. In other words, these floodplains are net importers of organic matter from the rivers. In addition to litterfall fluxes, atmospheric deposition could be a source of deposited nutrients. However, mean bulk atmospheric deposition of $\mathrm{P}$ in the Chesapeake region $\left(0.04 \mathrm{~g} \mathrm{~m}^{-2} \mathrm{y}^{-1}\right.$, Jordan and others 1995) and $\mathrm{N}$ in the watersheds of the seven rivers $\left(1.18 \mathrm{~g} \mathrm{~m}^{-2} \mathrm{y}^{-1}\right.$, USEPA Watershed Deposition Tool 1.4.10: National Atmospheric Deposition Program 2008) was small compared to their respective sediment depositional fluxes on floodplains. Regardless of the ultimate and proximate source of mineral and organic sediments and nutrients accumulating on floodplains, these fluxes represent retention of watershed loads that eventually would have been transported downstream, and therefore represent load interception.

\section{Sediment Erosion}

We assume that sediment deposited on these floodplains represents semi-permanent trapping. However, floodplains are geomorphically active 
environments with large amounts of sediment entrainment, transport, and deposition (Meade 1982). In our study, only $6-15 \%$ of the feldspar marker-horizons were eroded (Noe and Hupp 2005). Rates of channel migration and sediment reworking on the floodplain are also slow in the Coastal Plain of the Chesapeake Bay watershed (Hupp 2000). The alluvial floodplains of Coastal Plain rivers are often locations of great amounts of sediment storage due to the low slope and stream power below the Fall Line (Phillips and Slattery 2006). The residence time of floodplain sediments often exceeds 50 years (Meade 1982; Malmon and others 2002; Phillips and others 2007). Therefore, most sediment deposited at our study sites likely will remain in place over time scales relevant to human management of water quality. Elsewhere, in higher gradient systems, sediment deposition on floodplains can be balanced by sediment erosion through bank erosion (Arp and Cooper 2004; Schenk and Hupp, in press).

\section{Nutrient Mineralization or Release}

After deposition on floodplain soils, sedimentbound nutrients may undergo diagenesis that could result in export of $\mathrm{N}$ and $\mathrm{P}$ back to the main channel of the river. However, a biogeochemical bottleneck in these processes is the rate of organic $\mathrm{N}$ and $\mathrm{P}$ mineralization, but accurate in situ rates for wetland soils are unavailable. Laboratory assays indicate that less than $10 \%$ of wetland soil organic $\mathrm{N}$ or $\mathrm{P}$ pools are able to be mineralized (Bridgham and others 1998), suggesting that most particulate organic $\mathrm{N}$ and $\mathrm{P}$ deposited on floodplain surfaces is retained in its solid organic form. If deposited organic $\mathrm{N}$ was mineralized, the fluctuating hydrology and dynamic redox of floodplain soils is conducive to the enhancement of coupled $\mathrm{N}$ transformations that eventually result in denitrification (Reddy and Patrick 1984; Baldwin and Mitchell 2000). Alternatively, nitrate produced through mineralization and nitrification could be transported along hydrologic flowpaths back into flowing waters and exported downstream (Bechtold and others 2003). Deposited organic P also undergoes mineralization to orthophosphate, which can also desorb from mineral sediment under low redox conditions (Wetzel 1999). The orthophosphate produced by both reactions could either resorb to oxidized sediments or be exported along hydrologic flowpaths back to the river (Surridge and others 2007). An alternative pathway for inorganic $\mathrm{N}$ or P produced through mineralization is biotic uptake, followed by senescence and redeposition of organic nutrients to floodplain soils (for example, litterfall), resulting in continued storage and recycling of $\mathrm{N}$ and $\mathrm{P}$.

\section{Conclusions}

Non-tidal floodplains along Coastal Plain reaches of seven rivers in the Chesapeake Bay watershed had high rates of sediment and sediment-associated nutrient accumulation relative to their river loads. These sediment depositional fluxes represent a high percent retention of $\mathrm{N}, \mathrm{P}, \mathrm{C}$, and sediment transported by Coastal Plain rivers. Some uncertainty exists for scaling from plots to watersheds and for the permanency and sources of the deposited material on floodplains; further study would be required to resolve these issues. However, the material retained on floodplains still represents a decrease in loading to downstream systems even if the source of material depositing on floodplains is not from the river (that is, riparian buffering instead of riparian retention fluxes). Their high accumulation rates relative to river loads indicate that Coastal Plain floodplains have a quantitatively large role in intercepting and storing watershed material loads. Therefore, efforts to limit downstream sediment and nutrient loading to estuaries and coastal waters should ensure the function of floodplains is maintained or enhanced.

\section{ACKNOWLEDGMENTS}

This study was funded by the Chesapeake Bay Priority Ecosystem Science Program, the National Research Program, and the Hydrologic Networks and Analysis Program of the USGS. The authors would like to thank Dan Kroes, Tommy Donelson, Josh Ewell, and Hana Sanei for assistance in the field; Kathy Conko, Mike Doughten, and Jimmy Bae for help in the laboratory; Ed Schenk for estimating floodplain areas and inundation; Allen Gellis for providing sediment load data; Rich Alexander for providing SPARROW predictions; Lauren McPhillips for generating the map; and Rich Alexander, Charlie Demas, Dorothy Tepper, Des Walling, and two anonymous reviewers for comments on drafts of the manuscript. Any use of trade, product, or firm names is for descriptive purposes only and does not imply endorsement of the US Government.

\section{REFERENCES}

Alexander RB, Boyer EW, Smith RA, Schwarz GE, Moore RB. 2007. The role of headwater streams in downstream water quality. J Am Water Resour Assoc 43:41-59. 
Alexander RB, Smith RA, Schwarz GE, Boyer EW, Nolan JV, Brakebill JW. 2008. Differences in phosphorus and nitrogen delivery to The Gulf of Mexico from the Mississippi River basin. Environ Sci Technol 42:822-30.

Arp CA, Cooper DJ. 2004. Analysis of sediment retention in western riverine wetlands: The Yampa River watershed, Colorado, USA. Environ Manage 33:318-30.

Baldwin DS, Mitchell AM. 2000. The effects of drying and reflooding on the sediment and soil nutrient dynamics of lowland river-floodplain systems: a synthesis. Regul River Res Manage 16:457-67.

Baumann RH, Day JW Jr, Miller CA. 1984. Mississippi deltaic wetland survival: sedimentation versus coastal submergence. Science 224:1093-5.

Bechtold JS, Edwards RT, Naiman RJ. 2003. Biotic versus hydrologic control over seasonal nitrate leaching in a floodplain forest. Biogeochemistry 63:53-72.

Boomer KB, Weller DE, Jordan TE. 2008. Empirical models based on the universal soil loss equation fail to predict sediment discharges from Chesapeake Bay catchments. J Environ Qual 37:78-89.

Bridgham SD, Megonigal JP, Keller JK, Bliss NB, Trettin C. 2006. The carbon balance of North American wetlands. Wetlands 26:889-916.

Bridgham SD, Updegraff K, Pastor J. 1998. Carbon, nitrogen, and phosphorus mineralization in northern wetlands. Ecology 79:1545-61.

Brinson MM. 1988. Strategies for assessing the cumulative effects of wetland alteration on water quality. Environ Manage 12:655-62.

Brunet RC, Astin KB. 2000. A 12-month sediment and nutrient budget in a floodplain reach of the River Adour, Southwest France. Regul River Res Manage 16:267-77.

Clawson RG, Lockaby BG, Rummer B. 2001. Changes in production and nutrient cycling across a wetness gradient within a floodplain forest. Ecosystems 4:126-38.

Craft CB, Casey WP. 2000. Sediment and nutrient accumulation in floodplain and depressional freshwater wetlands of Georgia, USA. Wetlands 20:323-32.

Elder JF. 1985. Nitrogen and phosphorus speciation and flux in a large Florida river wetland system. Water Resour Res 21:72432.

Gellis AC, Hupp CR, Pavich MJ, Landwehr JM, Banks WSL, Hubbard BE, Langland MJ, Ritchie JC, Reuter JM. 2008. Sources, transport, and storage of sediment at selected sites in the Chesapeake Bay Watershed. U.S. Geological Survey Scientific Investigations Report 2008-5186.

Harvey JW, Wagner BJ. 2000. Quantifying hydrologic interactions between streams and their subsurface hyporheic zones. In: Jones JA, Mulholland PJ, Eds. Streams and ground waters. San Diego: Academic Press. p 3-44.

House WA, Leach D, Warwick MS, Whitton BA, Pattinson SN, Ryland G, Pinder A, Ingram J, Lishman JP, Smith SM, Rigg E, Denison FH. 1997. Nutrient transport in the Humber rivers. Sci Total Environ 194-195:303-20.

Hupp CR. 2000. Hydrology, geomorphology and vegetation of Coastal Plain rivers in the south-eastern USA. Hydrol Process 14:2991-3010.

Hupp CR, Woodside MD, Yanosky TM. 1993. Sediment and trace element trapping in a forested wetland, Chickahominy River, Virginia. Wetlands 13:95-104.
Hupp CR, Demas CR, Kroes DE, Day RH, Doyle TW. 2008. Recent sedimentation patterns within the central Atchafalaya Basin, Louisiana. Wetlands 28:125-40.

Hupp CR, Pierce A, Noe GB. 2009. Floodplain geomorphic processes, sedimentation, and ecological impacts of hydrologic alteration along Coastal Plain rivers, USA. Wetlands 29:41329.

Johnston CA. 1991. Sediment and nutrient retention by freshwater wetlands: effects on surface water quality. Crit Rev Environ Control 21:491-565.

Jordan TE, Correll DL, Weller DE, Goff NM. 1995. Temporal variation in precipitation chemistry on the shore of Chesapeake Bay. Water Air Soil Pollut 83:263-84.

Junk WJ, Bailey PB, Sparks RE. 1989. The flood pulse concept in river-floodplain systems. Can Spl Publ Fish Aquat Sci 106:110-27.

Kleiss BA. 1996. Sediment retention in a bottomland hardwood wetland in eastern Arkansas. Wetlands 16:321-33.

Langland MJ, Raffensperger JP, Moyer DL, Landwehr JM, Schwarz GE. 2006. Changes in streamflow and water quality in selected nontidal basins in the Chesapeake Bay watershed, 1985-2004. Reston, VA: USGS SIR-2006-5178.

Lockaby BG, Walbridge MR. 1998. Biogeochemistry. In: Messina MG, Conner WH, Eds. Southern forested wetlands-ecology and management. Boca Raton: Lewis Publishers. p 149-72.

Malmon DV, Dunne T, Reneau SL. 2002. Predicting the fate of sediment and pollutants in river floodplains. Environ Sci Technol 36:2026-32.

McClain ME, Boyer EW, Dent CL, Gergel SE, Grimm NB, Groffman PM, Hart SC, Harvey JW, Johnston CA, Mayorga E, McDowell WH, Pinay G. 2003. Biogeochemical hot spots and hot moments at the interface of terrestrial and aquatic ecosystems. Ecosystems 6:301-12.

Meade RH. 1982. Sources, sinks, and storage of river sediment in the Atlantic drainage of the United States. J Geol 90:235-52.

Mitsch WJ, Day JW, Zhang L, Lane R. 2005. Nitrate-nitrogen retention in wetlands in the Mississippi River basin. Ecol Eng 24:267-78.

National Atmospheric Deposition Program (NRSP-3). 2008. NADP Program Office, Illinois State Water Survey, 2204 Griffith Dr., Champaign, IL 61820.

National Research Council. 2002. Riparian areas: functions and strategies for management. Washington, DC: National Academy Press.

Noe GB, Hupp CR. 2005. Carbon, nitrogen, and phosphorus accumulation in floodplains of Atlantic coastal plain rivers, USA. Ecol Appl 15:1178-90.

Olde Venterink H, Vermaat JE, Pronk M, Wiegman F, Van der Lee GEM, Van den Hoorn MW, Higler LWG, Verhoeven JTA. 2006. Importance of sediment deposition and denitrification for nutrient retention in floodplain wetlands. Appl Veg Sci 9:163-74

Owens PN, Walling DE. 2002. Changes in sediment sources and floodplain deposition rates in the catchment of the River Tweed, Scotland, over the last 100 years: the impact of climate and land use change. Earth Surf Proc Land 27:423-30.

Phillips JD. 1989. Fluvial sediment storage in wetlands. Water Resour Bull 25:867-73.

Phillips JD, Slattery MC. 2006. Sediment storage, sea level, and sediment delivery to the ocean by coastal plain rivers. Prog Phys Geogr 30:513-30. 
Phillips JD, Marden M, Gomez B. 2007. Residence time of alluvium in an aggrading fluvial system. Earth Surf Proc Land 32:307-16.

Raymond PA, Bauer JE. 2001. Riverine export of aged terrestrial organic matter to the North Atlantic Ocean. Nature 409:497500.

Reddy KR, Patrick WH. 1984. Nitrogen transformations and loss in flooded soils and sediment. CRC Crit Rev Environ Control 13:273-309.

Richardson WB, Strauss EA, Bartsch LA, Monroe EM, Cavanaugh JC, Vingum L, Soballe DM. 2004. Denitrification in the Upper Mississippi River: rates, controls, and contribution to nitrate flux. Can J Fish Aquat Sci 61:1102-12.

Ross KM, Hupp CR, Howard AD. 2004. Sedimentation in floodplains of selected tributaries of the Chesapeake Bay. In: Bennett S, Simon A, Eds. Riparian vegetation and fluvial geomorphology. Washington, DC: American Geophysical Union. p 187-208.

Royer TV, David MG, Gentry LE. 2006. Timing of riverine export of nitrate and phosphorus from agricultural watersheds in Illinois: implications for reducing nutrient loading to the Mississippi River. Environ Sci Technol 40:4126-31.

Schenk ER, Hupp CR. Legacy effects of colonial millponds on modern floodplain sedimentation, bank erosion, and channel morphology, Mid Atlantic Region, USA. J Am Water Resour Assoc (in press).

Scott DT, Harvey JW, Noe GB. Combined effect of hydrologic connectivity and floodplain nitrogen processing on removal of nitrogen from a 5 th order southeastern US river. J Geophys Res Biogeosci (unpublished).

Steiger J, Gurnell AM, Goodson JM. 2003. Quantifying and characterizing contemporary riparian sedimentation. River Res Appl 19:335-52.
Surridge BWJ, Heathwaite AL, Baird AJ. 2007. The release of phosphorus to porewater and surface water from river riparian sediments. J Environ Qual 36:1534-44.

Sweet WV, Geratz JW. 2003. Bankfull hydraulic geometry relationships and recurrence intervals for North Carolina's coastal plain. J Am Water Resour Assoc 39:861-71.

Tockner K, Pennetzdorfer D, Reiner N, Schiemer F, Ward JV. 1999. Hydrological connectivity and the exchange of organic matter and nutrients in a dynamic river-floodplain system (Danube, Austria). Freshw Biol 41:521-35.

van der Lee GEM, Olde Venterink H, Asselman NEM. 2004. Nutrient retention in floodplains of the Rhine distributaries in the Netherlands. River Res Appl 20:315-25.

Walling DE, Quine TA. 1993. Using Chernobyl-derived fallout radionuclides to investigate the role of downstream conveyance losses in the suspended sediment budget of the River Severn, United Kingdom. Phys Geogr 14:239-53.

Walling DE, Owens PN, Leeks GJL. 1998. The role of channel and floodplain storage in the suspended sediment budget of the River Ouse, Yorkshire, UK. Geomorphology 22:225-42.

Walling DE, Owens PN, Leeks GJL. 1999. Rates of contemporary overbank sedimentation and sediment storage on the floodplains of the main channel systems of the Yorkshire Ouse and River Tweed, UK. Hydrol Process 13:993-1009.

Walter RC, Merritts DJ. 2008. Natural streams and the legacy of water-powered mills. Science 319:299-304.

Wetzel RG. 1999. Organic phosphorus mineralization in soils and sediments. In: Reddy KR, O'Connor GA, Schelske CL, Eds. Phosphorous biogeochemistry in subtropical ecosystems. Boca Raton: Lewis Publishers. p 225-48.

Xu YJ. 2006. Organic nitrogen retention in the Atchafalaya River Swamp. Hydrobiologia 560:133-43. 